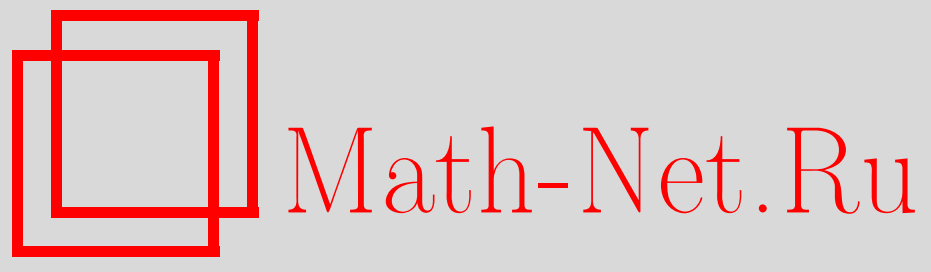

Конкурс Московского математического общества 2016 года, УМH, 2016, том 71, выпуск 2, 216

Использование Общероссийского математического портала Math-Net.Ru подразумевает, что вы прочитали и согласны с пользовательским соглашением http://www . mathnet.ru/rus/agreement

Параметры загрузки:

IP : 54.162 .85 .209

26 апреля 2023 г., 06:52:32

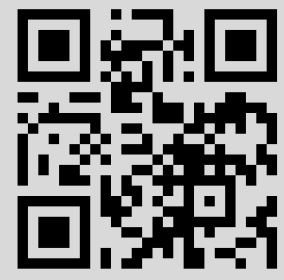




\section{Конкурс Московского математического общества 2016 года}

Премии Московского математического общества присуждаются молодым ученым за работу или цикл работ по математике, представляющих значительный научный интерес. Молодым считается ученый, которому в календарном году присуждения премии исполняется не более 30 лет.

Представлять работу или цикл работ на конкурс может любой член ММО.

Представляющий до 15 июня 2016 года присылает по электронному адресу konkursMMO@gmail.com:

- описание работ(ы) (если это цикл работ, то еще его общее название и список выдвигаемых работ);

- текст(ы) выдвигаемых работ в формате PDF;

- список возможных рецензентов и/или рекомендации других математиков (членство в ММО от рецензентов не требуется).

Решение о присуждении премии будет принято на заседании Правления MМО в сентябре 2016 года.

Денежная часть премии формируется при поддержке Российско-французской математической лаборатории им. Ж.-В. Понселе (CNRS и НMУ).

Объявление о конкурсе опубликовано на сайте ММО: http://mms.mathnet.ru/conc.php 